\title{
Education Research: Challenges Faced by Neurology Trainees in a Neuro-Intervention Career Track
}

Conrad W. Liang, MD, PhD, Saurav Das, MD, Santiago Ortega-Gutierrez, MD, MSc, David S. Liebeskind, MD, James C. Grotta, MD, Tudor G. Jovin, MD, Thanh N. Nguyen, MD, Raul G. Nogueira, MD, Hesham Masoud, MD, Lucas Elijovich, MD, Osama O. Zaidat, MD, Ameer E. Hassan, DO, Italo Linfante, MD, Johanna T. Fifi, MD, and Sunil A. Sheth, MD

Neurology ${ }^{\circledR}$ 2021;96:e2028-e2032. doi:10.1212/WNL.0000000000011629

\section{Abstract \\ Objective}

The widespread adoption of endovascular therapy (EVT) for emergent large vessel occlusion has led to increased nationwide demand for neurointerventionalists, heightened interest among neurology residents to pursue neurointervention as a career, and increased importance of neurointervention exposure for all neurologists who care for patients with acute ischemic stroke. Exposure to neurointervention and its career path are not well-defined for neurology trainees.

\section{Methods}

The Society for Vascular and Interventional Neurology (SVIN) Education Committee conducted a multicenter electronic survey directed towards neurology residents and vascular neurology (VN), neurocritical care (NCC), and neurointervention fellows in June 2018. A total of 250 programs were invited to participate; 76 trainees completed the survey.

\section{Results}

Respondents self-identified as 22\% postgraduate year (PGY)2, 40\% PGY3/4, 30\% VN fellows, and $8 \%$ neurointervention or NCC fellows. Eighty-seven percent of trainees had more than 2 months exposure to $\mathrm{VN}$ during residency, $41 \%$ to NCC, and only $3 \%$ to neurointervention. Sixty-eight percent of respondents had no exposure to neurointervention during residency. Whereas $72 \%$ believed that a background in neurology was good preparation for neurointervention, only $41 \%$ agreed that fellowship training pathway in neurointervention is wellstructured for neurology residents when compared to other subspecialties.

\section{Conclusion}

In this survey, respondents identified lack of exposure to neurointervention and a well-defined training pathway as obstacles towards pursuing neurointervention as a career. These obstacles must be addressed for the continued development of neurointervention as a subspecialty of neurology.

\author{
Correspondence \\ Dr. Liang \\ conrad.w.liang@kp.org
}




\section{Glossary}

EVT = endovascular therapy; LVO = large vessel occlusion; NCC = neurocritical care; PGY = postgraduate year; SVIN = Society for Vascular and Interventional Neurology; VN = vascular neurology.

Endovascular therapy (EVT) for emergent large vessel occlusion (LVO) has been shown to be one of the most efficacious treatments in modern medicine, and the widespread adoption of EVT has created a demand for qualified neurointerventionalists. ${ }^{1}$ Practicing neurointerventionalists today include neurologists, neurosurgeons, and radiologists. ${ }^{2}$ Neurology-trained neurointerventionists are uniquely positioned to provide full-service stroke care-from the initial patient evaluation in the emergency department, to thrombolytic administration and LVO thrombectomy, to critical care, inpatient, and consultative neurology services until hospital discharge and outpatient follow-up. Neurologists now comprise one-third of all certified neurointerventionalists, and neurology-trained interventionalists have served as principal investigators and led enrollment in several major EVT trials. ${ }^{3-5}$

The currently established pathway for neurology trainees interested in neurointervention is to complete residency (4 years), then a vascular neurology (VN) or neurocritical care (NCC) fellowship (1-2 years), followed by neurointervention fellowship (2 years). ${ }^{6}$ However, attaining a position in a neurointervention fellowship remains challenging for interested neurology residents. Potential barriers include limited exposure and access to the angiography suite during neurology residency, uncertainty regarding the application process for fellowship training, and a limited number of fellowship training positions. In order to better characterize the trainee experience, the Society for Vascular and Interventional Neurology (SVIN) Education Committee conducted a multicenter survey directed towards neurology residents, $\mathrm{VN}$ and NCC fellows, and neurointervention fellows.

\section{Methods}

A survey instrument (supplement 1, links.lww.com/WNL/ B328) was developed to determine self-reported exposure of the respondents to several aspects of neurointervention during their residency training. These included questions to assess perceptions regarding (1) exposure to procedural aspects of neurointervention; (2) comfort with clinical decisionmaking and patient management in the emergency department, angiography suite, and the neurointensive care unit; and (3) assessment of respondents' perceived interest and ability to pursue a career in neurointervention at the end of their current training. Trainees were identified by program directors from the American Association of Medical Colleges Electronic Residency Application Service 2019 participating neurology and vascular neurology programs list. Program Directors were emailed in June 2018 to ask their residents and fellows (including neurointervention and NCC fellows if they had such programs at their institute) to participate in the survey, with a reminder email a week later. The survey was open for 4 weeks following the initial email.

\section{Results}

A total of 250 programs were contacted, and 76 respondents completed the survey. Sixty-two percent of respondents selfreported as neurology residents, including $22 \%$ in postgraduate year (PGY) 2 and $40 \%$ in PGY3 or PGY4 of their residency training. Thirty-eight percent of respondents self-reported as fellows including 30\% from VN, 3\% from NCC, and 5\% from neurointervention (figure, A). Respondents were asked to characterize their clinical experience in VN, NCC, and neurointervention during residency. Most respondents (more than $70 \%$ ) reported more than 4 months of $\mathrm{VN}$ exposure, $47 \%$ reported 1-2 months of NCC exposure, whereas $68 \%$ reported the lack of any exposure to neurointervention during residency (figure, B). To evaluate familiarity with common clinical situations, responders were asked to rate their comfort in managing scenarios commonly encountered in $\mathrm{VN}$ and neurointervention. These questions and their results are listed in the figure, C. The majority of respondents felt comfortable or very comfortable determining whether a patient was a candidate for IV tissue plasminogen activator with an unknown time of onset based on MRI criteria (68\%); whether a patient was a candidate for EVT in the early and late time windows (86\%); identifying LVO (87\%); interpreting cerebral angiography (63\%); and managing subarachnoid hemorrhage in the neurointensive care unit (52\%). There was less comfort in assessing the post-thrombectomy Thrombolysis in Cerebral Infarction score on angiogram (65\% neutral or uncomfortable). Three questions were directed at evaluating the barriers facing neurology trainees interested in neurointervention (figure, D). A total of $65 \%$ felt welcome in the angiography suite to observe or participate in cases, and $72 \%$ felt that neurology base training would prepare them well for neurointervention fellowship. However, the majority of the respondents $(60 \%)$ felt that the pathway for pursuing a career in neurointervention was not well-structured for neurology residents compared to other neurologic subspecialties.

\section{Discussion}

This survey confirms that lack of clinical exposure and a clearly established training pathway remain significant barriers to neurology trainees interested in pursuing a career in neurointervention. Sixty percent of trainees in the survey felt that the path for pursuing a career in neurointervention was not wellstructured compared to other neurologic subspecialties. The power of the survey is limited by the low number of 


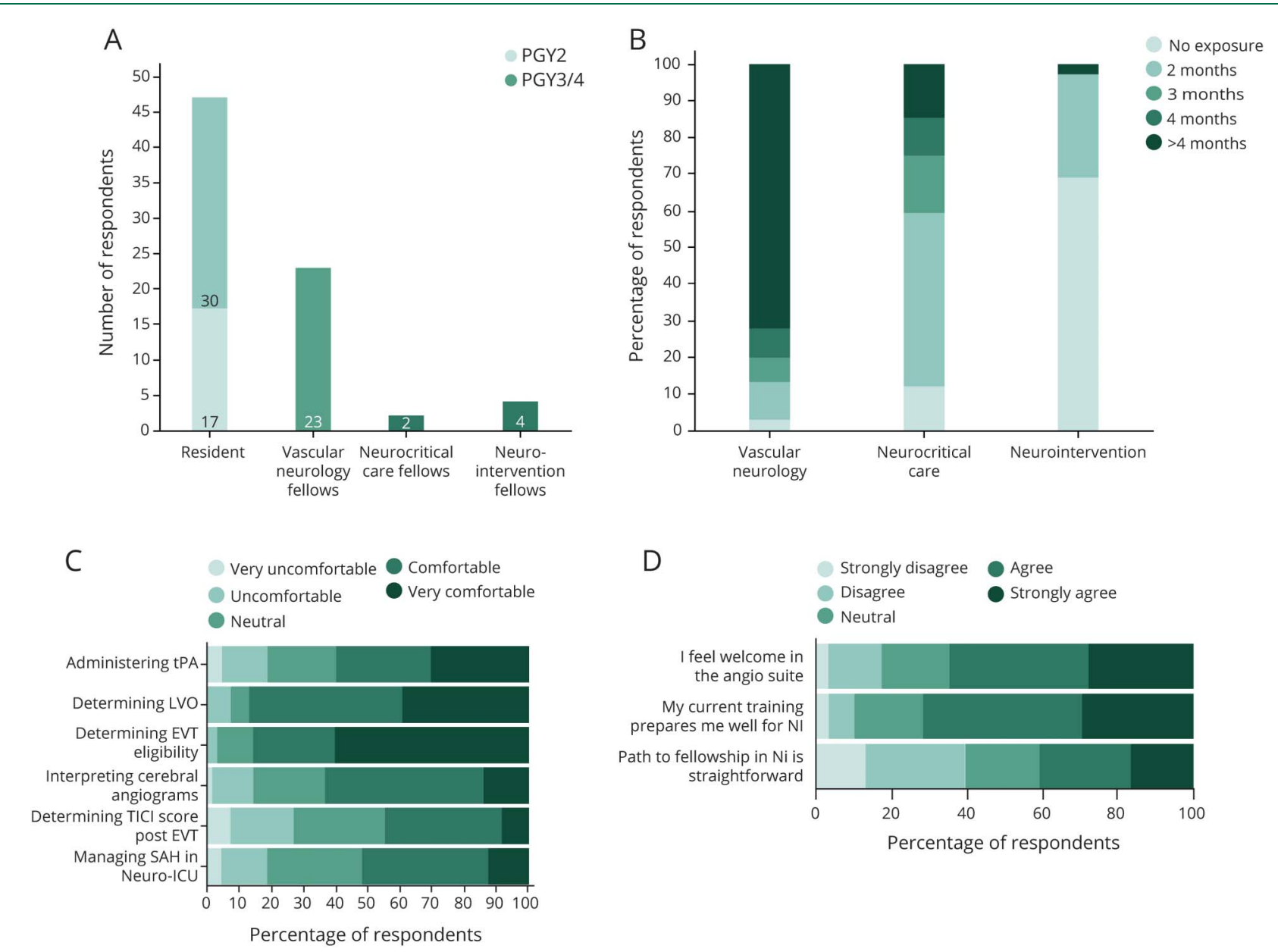

(A) Number of respondents, separated by level of training. (B) Exposure to vascular neurology, NCC, and neurointervention within training. (C) Familiarity with the clinical management of stroke, neurocritical care, and neurointervention patients. (D) Evaluation of the current training paradigm towards preparing for or obtaining fellowship training in neurointervention. EVT = endovascular therapy; ICU = intensive care unit; LVO = large vessel occlusion; NCC = neurocritical care; $\mathrm{NI}=$ neurointervention; $\mathrm{PGY}=$ postgraduate year; $\mathrm{SAH}=$ subarachnoid hemorrhage; $\mathrm{TICI}=$ Thrombolysis in Cerebral Infarction; $\mathrm{tPA}$ = tissue plasminogen activator.

respondents relative to the number of eligible trainees. Also, survey responders may be biased towards those interested in neurointervention, or those unhappy with their current exposure to neurointervention. These caveats notwithstanding, the results remain informative of the lack of neurointervention exposure in many neurology training curricula.

Neurointervention exposure is bound by the same constraints that all neurology subspecialties face. There is usually oblique interaction with the neurointervention service during rotation time on vascular neurology or general neurology. However, focused elective time may be more difficult to arrange, especially if the neurointervention service is housed under a different department (e.g., radiology or neurosurgery). Absence of neurology-trained neurointervention physicians also limits resident exposure to the field, and lack of faculty mentors increases the difficulty for interested residents during the career exploration and, later, the fellowship application period. Academic faculty members play an important role in encouraging the development and specialization of resident physicians, and neurology-trained neurointervention academic faculty members can be instrumental in designing a structured neurointervention exposure for neurology residents as well as during medical students' neurology rotation. ${ }^{7}$ This may include hands-on experiences in the angiography suite, clinical experience on the neurovascular intensive care unit and wards, simulation laboratory studies, and silicone bench models for exposure to the devices and techniques used in day-to-day practice. ${ }^{8}$ Virtual reality simulation has been recently reported to accelerate the learning curve in neurointervention. ${ }^{9}$ Neurologists in the real world are often the first (and sometimes only) specialists to evaluate and treat stroke, and so familiarity with the indications for neurointervention procedures should be considered a core competency for graduation. Early exposure to neurointervention for medical students and neurology residents is a crucial element towards producing well-trained neurologists while also bolstering the competitiveness of neurology candidates for neurointervention fellowships. 
Establishing a formal training pathway for neurology to neurointervention is another key component to enable neurology residents to successfully compete for neurointervention fellowship positions. For these residents, securing a position is not straightforward. First, the application deadline for neurointervention programs varies widely, and interview dates may range from 1 to 4 years before beginning fellowship. Some programs start interviewing in the year immediately preceding the start of fellowship, while others may interview 3 or 4 years in advance of the fellowship start date. Given the heterogeneous pool of applicants, residents from different specialties are often at different stages in their training by the application date. Late deciders (e.g., VN or NCC fellows) will be excluded from programs that interview years in advance. These timing issues ensure that only neurology residents who begin residency with a plan to pursue neurointervention, or those who take gap years between residency and fellowship, will be able to apply to the breadth of available programs. Combining neurointervention with a $\mathrm{VN}$ or NCC fellowship application process will ease the uncertainty in applying for 2 fellowships simultaneously and make neurointervention more attainable for neurology residents.

Neurosurgery and radiology residents receive dedicated exposure to neurointervention, and their specialties have a timeestablished pathway to pursue fellowship and certification in neurointervention. Parity in clinical exposure and accreditation for neurology-based trainees is an issue currently undergoing active and vigorous debate, and one that would benefit greatly from the attention and involvement of the broader neurology community. Within neurology, clinical exposure to neurointervention in residency, mentorship from neurology-trained neurointervention faculty, and a straightforward path to fellowship remain sorely lacking, despite the rapidly increasing demand for stroke specialists and neurointerventionists to treat LVO. Providing a barrier-free pathway to certification for neurologists trained in neurointervention should be a priority for our specialty organizations such as the American Academy of Neurology and SVIN.

Neurologists bring an important clinical perspective to the daily practice of neurointervention. Knowledge and experience in the acute and long-term management of patients with stroke provides a balanced perspective for the neurointervention provider when faced with a difficult LVO situation, such as a patient with a low NIH Stroke Scale score, with distal vessel occlusion, or with a partially occluded vessel. This dual perspective is important for good clinical decisionmaking when information is incomplete and timing is critical. Many communities in the United States today do not have timely access to stroke thrombectomy. It is imperative that neurology take an active role with neurosurgery and radiology in producing qualified physicians to make these valuable and life-saving services widely available and accessible.

\section{Study Funding}

No targeted funding reported.

\section{Disclosure}

S. Ortega-Gutierrez reports no disclosures pertinent to this work and is a consultant for Medtronic and Stryker. D.S. Liebeskind is a consultant for Cerenovus, Genentech, Stryker, and Medtronic. I. Linfante is a consultant for Medtronic, Stryker, Cerenovus, and Prolong Pharmaceuticals and hold stock in InNeuroCo and Deinde. The remaining authors report no disclosures pertinent to this work. Go to Neurology.org/N for full disclosures.

\section{Appendix Authors}

\begin{tabular}{|c|c|c|}
\hline Name & Location & Contribution \\
\hline $\begin{array}{l}\text { Conrad W. } \\
\text { Liang, MD, PhD }\end{array}$ & $\begin{array}{l}\text { Kaiser Permanente Fontana } \\
\text { Medical Center, CA; UC } \\
\text { Riverside School of Medicine, CA }\end{array}$ & $\begin{array}{l}\text { Conceptualization } \\
\text { and manuscript } \\
\text { writing }\end{array}$ \\
\hline Saurav Das, MD & $\begin{array}{l}\text { Washington University School } \\
\text { of Medicine, St. Louis, MO }\end{array}$ & $\begin{array}{l}\text { Conceptualization } \\
\text { and manuscript } \\
\text { writing }\end{array}$ \\
\hline $\begin{array}{l}\text { Santiago } \\
\text { Ortega- } \\
\text { Gutierrez, MD, } \\
\text { MSc }\end{array}$ & University of Iowa, lowa City & $\begin{array}{l}\text { Conceptualization } \\
\text { and manuscript } \\
\text { writing }\end{array}$ \\
\hline $\begin{array}{l}\text { David S. } \\
\text { Liebeskind, MD }\end{array}$ & $\begin{array}{l}\text { University of California, Los } \\
\text { Angeles, CA }\end{array}$ & $\begin{array}{l}\text { Conceptualization } \\
\text { and manuscript } \\
\text { writing }\end{array}$ \\
\hline $\begin{array}{l}\text { James C. Grotta, } \\
\text { MD }\end{array}$ & $\begin{array}{l}\text { Memorial Hermann Hospital- } \\
\text { Texas Medical Center, Houston }\end{array}$ & $\begin{array}{l}\text { Conceptualization } \\
\text { and manuscript } \\
\text { writing }\end{array}$ \\
\hline $\begin{array}{l}\text { Tudor G. Jovin, } \\
\text { MD }\end{array}$ & $\begin{array}{l}\text { Cooper University Hospital, } \\
\text { Cooper Medical School of } \\
\text { Rowan University, Camden, NJ }\end{array}$ & $\begin{array}{l}\text { Conceptualization } \\
\text { and manuscript } \\
\text { writing }\end{array}$ \\
\hline $\begin{array}{l}\text { Thanh N. } \\
\text { Nguyen, MD }\end{array}$ & $\begin{array}{l}\text { Boston Medical Center, Boston } \\
\text { University School of Medicine, } \\
\text { MA }\end{array}$ & $\begin{array}{l}\text { Conceptualization } \\
\text { and manuscript } \\
\text { writing }\end{array}$ \\
\hline $\begin{array}{l}\text { Raul G. } \\
\text { Nogueira, MD }\end{array}$ & $\begin{array}{l}\text { Marcus Stroke \& Neuroscience } \\
\text { Center, Grady Memorial } \\
\text { Hospital, Emory University } \\
\text { School of Medicine, Atlanta, GA }\end{array}$ & $\begin{array}{l}\text { Conceptualization } \\
\text { and manuscript } \\
\text { writing }\end{array}$ \\
\hline $\begin{array}{l}\text { Hesham } \\
\text { Masoud, MD }\end{array}$ & $\begin{array}{l}\text { State University of New York } \\
\text { Upstate Medical University, } \\
\text { Syracuse }\end{array}$ & $\begin{array}{l}\text { Conceptualization } \\
\text { and manuscript } \\
\text { writing }\end{array}$ \\
\hline $\begin{array}{l}\text { Lucas Elijovich, } \\
\text { MD }\end{array}$ & $\begin{array}{l}\text { Semmes-Murphey Clinic, } \\
\text { University of Tennessee Health } \\
\text { Science Center, Memphis, TN }\end{array}$ & $\begin{array}{l}\text { Conceptualization } \\
\text { and manuscript } \\
\text { writing }\end{array}$ \\
\hline $\begin{array}{l}\text { Osama O. } \\
\text { Zaidat, MD }\end{array}$ & $\begin{array}{l}\text { BSMH St Vincent Medical } \\
\text { Center, Toledo, } \mathrm{OH}\end{array}$ & $\begin{array}{l}\text { Conceptualization } \\
\text { and manuscript } \\
\text { writing }\end{array}$ \\
\hline $\begin{array}{l}\text { Ameer E. } \\
\text { Hassan, DO }\end{array}$ & $\begin{array}{l}\text { University of Texas Rio Grande } \\
\text { Valley, Harlingen }\end{array}$ & $\begin{array}{l}\text { Conceptualization } \\
\text { and manuscript } \\
\text { writing }\end{array}$ \\
\hline $\begin{array}{l}\text { Italo Linfante, } \\
\text { MD }\end{array}$ & $\begin{array}{l}\text { Miami Cardiac and Vascular } \\
\text { Institute, FL }\end{array}$ & $\begin{array}{l}\text { Conceptualization } \\
\text { and manuscript } \\
\text { writing }\end{array}$ \\
\hline $\begin{array}{l}\text { Johanna T. Fifi, } \\
\text { MD }\end{array}$ & $\begin{array}{l}\text { Mount Sinai Hospital, New York, } \\
\text { NY }\end{array}$ & $\begin{array}{l}\text { Conceptualization } \\
\text { and manuscript } \\
\text { writing }\end{array}$ \\
\hline $\begin{array}{l}\text { Sunil A. Sheth, } \\
\text { MD }\end{array}$ & $\begin{array}{l}\text { UTHealth McGovern Medical } \\
\text { School, Houston, TX }\end{array}$ & $\begin{array}{l}\text { Conceptualization } \\
\text { and manuscript } \\
\text { writing }\end{array}$ \\
\hline
\end{tabular}




\section{References}

1. Rai AT, Seldon AE, Boo S, et al. A population-based incidence of acute large vessel occlusions and thrombectomy eligible patients indicates significant potential for growth of endovascular stroke therapy in the USA. J Neurointerv Surg 2017;9:722-726.

2. Strozyk D, Hanft SJ, Kellner CP, Meyers PM, Lavine SD. Training in endovascular surgical neuroradiology. World Neurosurg 2010;74:28-31.

3. Albers GW, Marks MP, Kemp S, et al. Thrombectomy for stroke at 6 to 16 hours with selection by perfusion imaging. N Engl J Med 2018;378:708-718.

4. Jovin TG, Chamorro A, Cobo E, et al. Thrombectomy within 8 hours after symptom onset in ischemic stroke. N Engl J Med 2015;372:2296-2306.

5. Nogueira RG, Jadhav AP, Haussen DC, et al. Thrombectomy 6 to 24 hours after stroke with a mismatch between deficit and infarct. N Engl J Med 2018;378:11-21.
6. Chen M, Nguyen T. Emerging subspecialties in neurology: endovascular surgical neuroradiology. Neurology 2008;70:e21-e24.

7. Leschke J. The future role of interventional neurology: a survey of neurology department program directors and clerkship directors. Neurology 2014;82: P4.242.

8. Paramasivam S, Baltsavias G, Psatha E, Matis G, Valavanis A. Silicone models as basic training and research aid in endovascular neurointervention: a single-center experience and review of the literature. Neurosurg Rev 2014;37:331-337; discussion 337.

9. Liebig T, Holtmannspotter M, Crossley R, et al. Metric-based virtual reality simulation: a paradigm shift in training for mechanical thrombectomy in acute stroke. Stroke 2018;49:e239-e242. 


\section{Neurology}

\section{Education Research: Challenges Faced by Neurology Trainees in a Neuro-Intervention Career Track}

Conrad W. Liang, Saurav Das, Santiago Ortega-Gutierrez, et al.

Neurology 2021;96;e2028-e2032 Published Online before print February 12, 2021

DOI 10.1212/WNL.0000000000011629

This information is current as of February 12, 2021

$\begin{array}{ll}\begin{array}{l}\text { Updated Information \& } \\ \text { Services }\end{array} & \begin{array}{l}\text { including high resolution figures, can be found at: } \\ \text { http://n.neurology.org/content/96/15/e2028.full }\end{array} \\ \text { References } & \text { This article cites } 9 \text { articles, } 3 \text { of which you can access for free at: } \\ & \text { http://n.neurology.org/content/96/15/e2028.full\#ref-list-1 } \\ & \text { This article has been cited by } 1 \text { HighWire-hosted articles: } \\ & \text { http://n.neurology.org/content/96/15/e2028.full\#\#therarticles } \\ \text { Citations } & \text { This article, along with others on similar topics, appears in the } \\ & \text { following collection(s): } \\ \text { All Cerebrovascular disease/Stroke } & \text { http://n.neurology.org/cgi/collection/all_cerebrovascular_disease_strok } \\ \text { Subspecialty Collections } & \text { All Education } \\ & \text { http://n.neurology.org/cgi/collection/all_education } \\ & \text { Information about reproducing this article in parts (figures,tables) or in } \\ & \text { its entirety can be found online at: } \\ & \text { http://www.neurology.org/about/about_the_journal\#permissions } \\ \text { Permissions \& Licensing } & \text { Information about ordering reprints can be found online: } \\ & \text { http://n.neurology.org/subscribers/advertise }\end{array}$

Neurology ${ }^{\circledR}$ is the official journal of the American Academy of Neurology. Published continuously since 1951, it is now a weekly with 48 issues per year. Copyright (C 2021 American Academy of Neurology. All rights reserved. Print ISSN: 0028-3878. Online ISSN: 1526-632X.

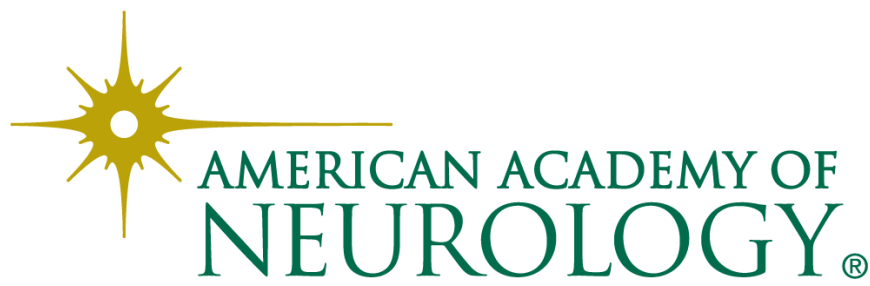

